Research Article

\title{
Effect of Forest Management Types on Soil Carbon Stocks in Montane Forests: A Case Study of Eastern Mau Forest in Kenya
}

\author{
George K. Tarus $\mathbb{D}^{1}$ and Stanley W. Nadir $\mathbb{D}^{2}$ \\ ${ }^{1}$ Kenya Forest Service, P.O Box 30513-00100, Nairobi, Kenya \\ ${ }^{2}$ Kenya Forestry Research Institute, P.O Box 20412-00200, Nairobi, Kenya \\ Correspondence should be addressed to George K. Tarus; tarus2014@gmail.com
}

Received 21 April 2020; Revised 29 August 2020; Accepted 10 September 2020; Published 7 October 2020

Academic Editor: Nikolaos D. Hasanagas

Copyright (c) 2020 George K. Tarus and Stanley W. Nadir. This is an open access article distributed under the Creative Commons Attribution License, which permits unrestricted use, distribution, and reproduction in any medium, provided the original work is properly cited.

\begin{abstract}
Mau Forest, a major forest reserve in Kenya, has experienced anthropogenic disturbances through encroachment and forest fires. This study aimed at comparing the soil carbon stocks in different forest management types as well as how seasonal climatic changes influence its dynamics. The study was undertaken in the Eastern Mau block (Sururu) which forms part of the greater Mau Forest Complex. The forest management interventions have been in place for over 15 years with disturbed (fire) natural forest experiencing fires in 2005, 2007, and 2014 while cypress plantations were established in 1994. A nested experimental design was used in data collection, where thirty-two sample plots were nested into four blocks each measuring $100 \mathrm{~m}^{2}$ delineated by forest management types (disturbed by fire, natural forest, undisturbed natural forest, plantation, and glades). In each plot, data on soil carbon stocks, soil bulk density, soil moisture, and temperature were collected for both dry and wet seasons. Data collection was carried out between November 2015 and December 2016. The results indicated that there were no significant differences in the carbon stocks among the forest management types $\left(F_{4,16}=0.61, P=0.613\right)$. However, seasonal weather changes significantly affected the amount of carbon stocks among the forest management types $\left(F_{4,16}=0.61, P>0.05\right)$. The undisturbed natural forest had the highest mean soil carbon stocks, while the plantation forest had the lowest as follows: undisturbed natural forest $\left(135.17 \pm 35.99 .0 \mathrm{Mg} \cdot \mathrm{C}^{-\mathrm{ha}}\right)$, disturbed natural forest by fire $\left(134.52 \pm 38.11 \mathrm{Mg} \cdot \mathrm{C}^{- \text {ha }}\right)$, glades $\left(122.4 \pm 64.9 \mathrm{Mg} \cdot \mathrm{C}^{-\mathrm{ha}}\right)$, and plantation forest $\left(116.51 \pm 39.77 \mathrm{Mg} \cdot \mathrm{C}^{-\mathrm{ha}}\right)$. Furthermore, the undisturbed natural forest management had the highest bulk density $(0.66 \mathrm{~g} /$ $\mathrm{cm}^{3}$ ), while the disturbed (fire) natural forest had the lowest $\left(0.59 \mathrm{~g} / \mathrm{cm}^{3}\right)$. These values were low compared to most normal mineral soils which have a bulk density of between $1.0 \mathrm{~g} / \mathrm{cm}^{3}$ and $1.5 \mathrm{~g} / \mathrm{cm}^{3}$. There was a significant $(P>0.01)$ relationship between seasonal weather (temperature) changes and soil carbon stocks under different forest management types with the relationship being stronger in soils under glades $\left(r^{2}=0.62\right)$ and weak in the undisturbed natural forest $\left(r^{2}=0.26\right)$. In conclusion, forest disturbances have an impact on soil carbon stocks, and for effective management of forest towards climate stabilization, then disturbance should be minimized if not avoided.
\end{abstract}

\section{Introduction}

Forest soils are a major sink of terrestrial carbon containing more than double the amount of carbon found in forest tree biomass $[1,2]$ and play a fundamental role in the global carbon cycle [3-6]. The role of forest soils as either a source or sink has become vital when assessing changes in atmospheric carbon dioxide concentrations mainly due to the growing interest of reducing the greenhouse emissions [7-10].
Traditionally, forest management practices focused mainly on increasing the forest productivity and growing biomass stock with little effort on managing the soil carbon. Even though the effects of forest management on soil carbon stocks are not well understood [11], consensus exists that some forest management operations have an impact on carbon budget including losses of carbon from mineral soils [12].

Forest management operations have been known to affect the carbon gains and losses by changing the level of 
inputs to the soil carbon pools, rates of microbial decomposition, changing environmental conditions such as temperature and moisture, and changing the quality of litter $[2,11]$. Variability in weather parameters especially temperature and soil moisture has been reported to influence soil organic matter decomposition [13]. In addition, wet and cold climates store more soil carbon compared to dry and hot climates with suggestions of the existing optimum climate influencing soil carbon storage [14]. Seasonal dry and wet conditions have no significant change in total soil carbon in tropical forests [15] although biomass accumulation in disturbed forests is reported to be influenced by temperature [16].

The Mau Forest Complex (MFC) forms the largest closed-canopy forest ecosystem in Kenya, covering over 400,000 hectares of land [17, 18]. This forest ecosystem is comprised of several forest blocks including the Eastern Mau Forest block. MFC provides critical ecological goods and services such as river flow regulation, flood mitigation, recharge of groundwater, reduced soil erosion and siltation, water purification, conservation of biodiversity, and microclimate regulation $[17,19,20]$. Despite the above critical functions, the Mau Forest Complex has been impacted by extensive irregular and ill-planned settlements as well as illegal forest resource extraction that have reduced the cover by more than $7 \%$ in the past 21 years [21]. To address these negative trends, the government enhanced forest management through the deployment of various interventions including both policy and restoration measures.

The forest reserve is being subjected to heterogeneous management to address the varied previous disturbance levels and existing resource types. These management activities are anticipated to affect the carbon dynamics such as carbon emissions and sequestration.

Therefore, the aim of this study was to evaluate the impacts of the forest management on the soil carbon stocks in the Eastern Mau Forest reserve. The findings of this study contribute knowledge towards carbon management, climate change mitigation mechanisms such as Reduction of Emission from Deforestation and forest Degradation $(\mathrm{REDD}+)$, and the role of conservation in the sustainable management of forests and enhancement of forest carbon stocks and climate change policies.

\section{Materials and Methods}

\subsection{Description of the Study Area}

2.1.1. Location. This study was undertaken in Sururu forest block (Figure 1). The block is part of the larger East Mau Forest reserve. The selection of the study site was centered on the application of management objectives (plantation forest, undisturbed natural forest, disturbed (fire) natural forest, and glades). The management actions are critical in the development, conservation, and management of Kenya's forest resources [17]. The Eastern Mau Forest is $50 \mathrm{~km}$ south of Nakuru Town and positioned within UTM zone 37S and the coordinate bounds (161237, 9937639); (161237, 9924748); (1773018, 9937639); (1773018, 9924748) (KFS,
2011) (Figure 1). Sururu forest block covers an area of approximately 13364.4 ha $[17,20]$. Despite the complexity in the plant formation, there is a broad altitudinal zonation. The lower zone is comprised of lower montane forest which occurs below $2,300 \mathrm{~m}$ and then it transitions into middle montane at $2350 \mathrm{~m}$. The middle montane is composed of thickets of bamboo (Arundinaria alpine) mixed with forest. The upper zone ranging from $2420 \mathrm{~m}$ to $2600 \mathrm{~m}$ at the escarpment crest forms the upper montane Sclerophyllous forest. The optimal conditions for forest growth are within the lower montane forest zone. This zone is characterized by tree species that include Aningeria adolfi-friedericii and Strombosia scheffleri [18]. Some of the major rivers and streams forming up the hydrological systems of Lake Victoria, Lake Nakuru, Lake Baringo, and Lake Natron originate from Eastern Mau, thus making it a critical watershed within the Mau Forest Complex [20].

2.1.2. Soils. The area is dominated by Nitisols, Ferralsols, Acrisols, and Cambisols in the highlands with high contents of silt and clay. In the lowlands, Luvisols, Vertisols, Planosols, and Cambisols formed from Holocene sedimentary deposits occur $[22,23]$. The top soils are clay loams and silt in the subsoil with $\mathrm{pH}$ ranging between 5.6 and 6.4, making them slightly and moderately acidic in nature. The soils are generally well drained, deep, dark to greyish brown, and friable with thick humic top horizon. These soils support the intensive agricultural activities around the forest, and as a result, the region has high human population densities [19].

The topography of the area is made up of the escarpments, hills, rolling lands, and plains with slopes ranging from $2 \%$ to $30 \%$ developed on quaternary and tertiary volcanic deposits [23].

2.1.3. Climate. The study area has a trimodal precipitation pattern with the long and intense rains from April to June, short rains in August, and shorter and less intense rains from November to December with mean monthly rainfall between $30 \mathrm{~mm}$ and $120 \mathrm{~mm}$, and a total annual precipitation of $1200 \mathrm{~mm}$ [20]. The area has a dry spell between January and March, and September and October with annual temperature ranges of $17-23^{\circ} \mathrm{C}$. The climatic conditions of Sururu forest are influenced by altitude and aspect [24]. The weather of Mau complex is largely influenced by the northsouth movement of the Intertropical Convergence Zone (ITCZ) modified by local orographic effects.

\subsection{Forest Management in Sururu Forest Block/Forest} Characteristics. The forest block is characterized by a wide range of plant and wildlife species. The study area has a dense canopy forest with diverse tree species. Sururu forest block can be delineated into strata based on management types, i.e., natural forest, plantations, and glades. The major functions of natural forest management type are to deliver a range of ecosystem goods and services continuously, conserve the diverse flora and fauna, and provide climate system services. The disturbed (fire) natural forest experienced 


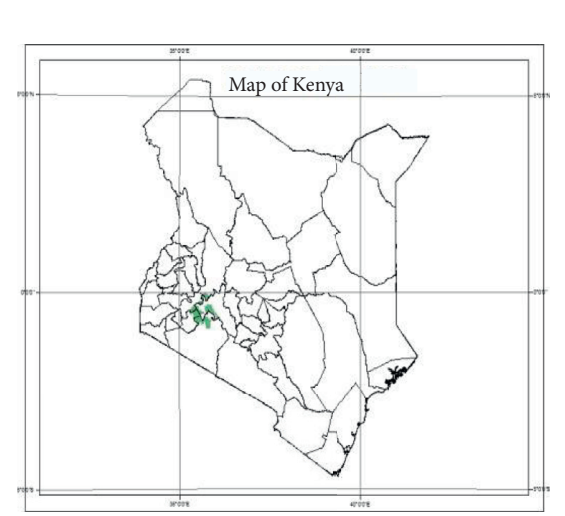

(a)
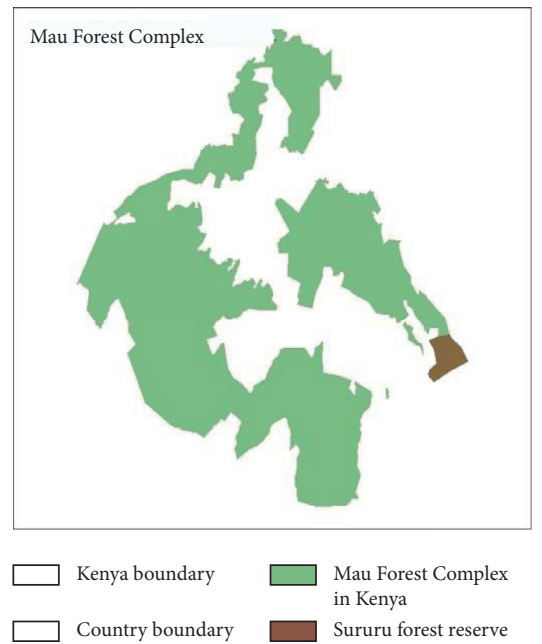

(b)

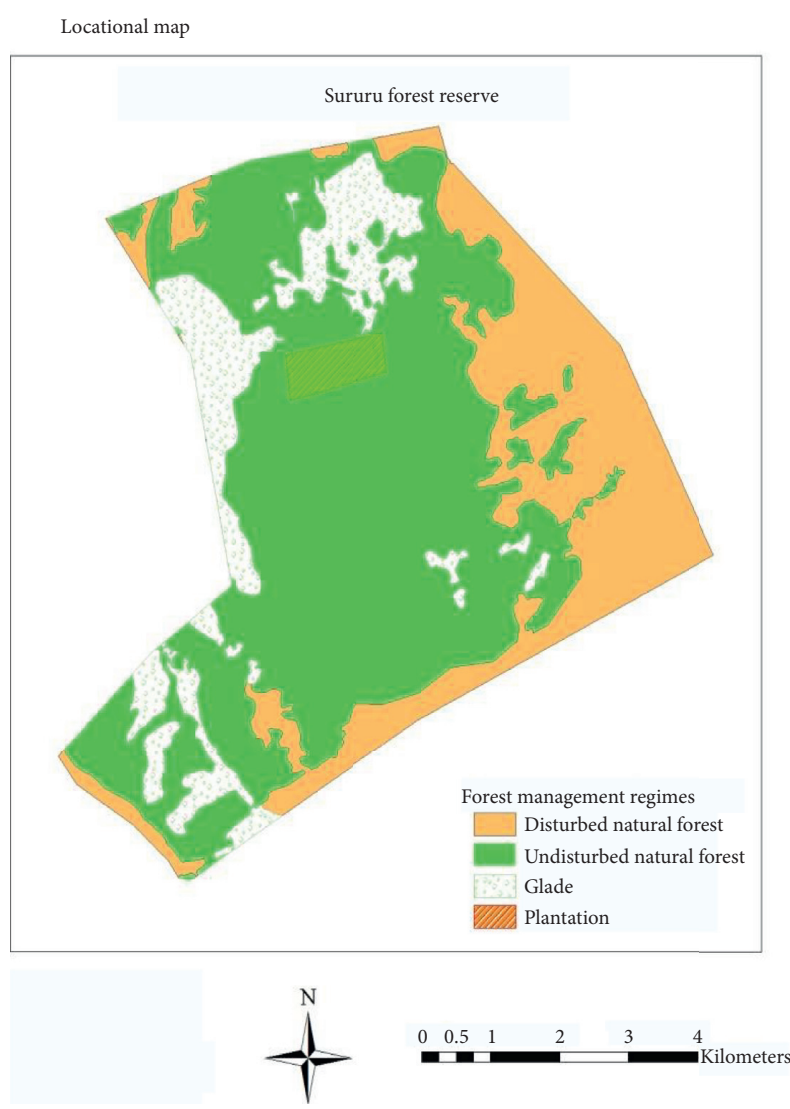

(c)

Figure 1: Map of the study area within Kenya (a), within Mau Forest Complex (b), and Sururu Forest (c).

forest fire events in 2005, 2007, and 2014 and therefore is covered by a mix of plant regenerates. This management intervention focuses on natural recovery of the forest after the experienced disturbance. Some of the actions include closure for natural regeneration and limited human intervention in form of forest fire management and aided regeneration in section with depleted seed sources. The plantation management is comprised of establishment of forests in even age or uneven age monocultures or mixed species. Sites were selected within 12 hectares cypress (Cupressus lusitanica) forest planted in 1994 to represent plantation management type. The glades cover approximately 1200 hectares and are fragmented within the forest block [18]. Due to the uniqueness of the strata, a set of operations are required to achieve the management objectives. The study classified the natural forest into two classes due to the required strategies in the disturbed (fire) and undisturbed sites.

2.3. Research Design and Sampling Methodology. The study used the nested experimental research design approach. Two systematic blocks measuring $50 \mathrm{~m}$ by $50 \mathrm{~m}$ within each of the four forest management types (plantation, undisturbed natural forest, disturbed (fire) natural forest, and glades) were established. In each block, four random plots measuring $10 \mathrm{~m}$ by
$10 \mathrm{~m}$ were nested, and in each plot, five random soil auger points were identified for sampling. To understand the effect of seasonality on soil carbon dynamics, data collection was compartmentalized for dry and wet seasons with daily temperature and weekly soil moisture content being recorded. The dry season began in January to March, and the rainy season started from April to June.

2.4. Measurement of Soil Organic Carbon (SOC). Soil carbon stocks were estimated from both the soil organic carbon (SOC) and soil organic matter (SOM) contents. The organic matter $(\mathrm{OM})$ content was determined using the loss-onignition (LOI) method and the organic carbon (OC) by the Walkley and Black method through titration $[25,26]$.

For the loss-on-ignition (LOI) method, the soil samples were collected at five random points within the plots measuring $10 \mathrm{~m}$ by $10 \mathrm{~m}$ at $0-10 \mathrm{~cm}$ depth to make a composite sample as described in Section 2.3. The samples were oven-dried, crushed using mortar and pestle to homogenize, and then sieved using a $2 \mathrm{~mm}$ mesh to remove debris. Two samples weighing 5 grams each were put in a preweighed crucible and then combusted at $550^{\circ} \mathrm{C}$ for 8 hours and then cooled before their weight was recorded. The differences in mass of weights of soil before and after heating represented the moisture and organic matter 
content while the residue represented the ash. The soil organic carbon (SOC) was derived using the following equation:

$$
\text { SOC content }=\frac{\text { initial weight }(\mathrm{g})-\text { final weight }(\mathrm{g})}{\text { initial weight }(\mathrm{g})} \times 100 \text {. }
$$

2.5. Quantification of Soil Total Carbon (TOC) Stocks. The organic carbon in the soil was also determined as per the Walkley and Black titration method by subjecting the soil to complete oxidation (sulphuric acid and aqueous potassium dichromate mixture) followed by titration using ferrous ammonium sulphate on the unused potassium dichromate as outlined $[25,26]$. The difference between added and residual potassium dichromate gives a measure of organic carbon content of soil. The soil organic carbon (SOC) determined by the two methods was compared (means) and used to estimate total organic carbon (TOC) for the study area as shown in the following equation:

$$
\operatorname{TOC}\left(\mathrm{tCha}^{-1}\right)=\text { bulk density } * \text { soil depth interval }(\mathrm{cm}) * \% C \text {, }
$$

where 1 tonne $=1,000,000 \mathrm{~g} ; 1 \mathrm{tC} / \mathrm{ha}=1,000,000 \mathrm{~g} \cdot \mathrm{C} / \mathrm{ha}=1$ $\mathrm{Mg} \cdot \mathrm{C} / \mathrm{ha} ; \mathrm{M}=$ million.

Soil bulk density was determined using the core ring method from the soil water content measured gravimetrically. Detailed information is found in documented standard protocols [26, 27]. Gravimetric soil moisture content was measured by taking a soil sample at a depth of $0-5 \mathrm{~cm}$ at five points within the plot (measuring $10 \mathrm{~m}$ by $10 \mathrm{~m}$ ). The core ring samplers were weighed before soil sampling. The samples were weighed before oven drying for $24 \mathrm{~h}$ at $105^{\circ} \mathrm{C}$ and reweighed after cooling. The moisture content was determined by mass difference as described in $[26,27]$. To estimate soil bulk density, the oven-dried soils mass were utilized after soil moisture determination as shown in the following equation:

$$
\text { bulk density }\left(\mathrm{gcm}^{-3}\right)=\frac{\text { mass of oven }- \text { dried sample }(\mathrm{g})}{\text { volume of the sample }\left(\mathrm{cm}^{3}\right)} \text {. }
$$

2.6. Data Analysis. The collected data were subjected to tests of normality and homogeneity of variance before transformation. Variations in soil carbon stocks among the different forest management types were assessed using analysis of variance (ANOVA). Linear regression analysis on seasonal changes in soil carbon under different forest management types was also undertaken using soil carbon stocks as the response variable while bulk density, temperature, and soil moisture as explanatory variables. GenStat edition 16 statistical software was used for data analysis [28].

\section{Results}

3.1. Effect of Forest Management Types on Soil Carbon Stocks. Generally, there were no significant differences in the carbon stocks among the four forest management types irrespective of seasonal weather changes $\left(F_{4},{ }_{16}=0.61\right.$, $P=0.53)$. The undisturbed natural forest had the highest mean soil carbon stocks $(135.2 \pm 360 \mathrm{Mg} \cdot \mathrm{C} / \mathrm{ha})$ followed by disturbed natural forest $(134.5 \pm 38.1 \mathrm{Mg} \cdot \mathrm{C} / \mathrm{ha})$, glades $(122.4 \pm 64.9 \mathrm{Mg} \cdot \mathrm{C} / \mathrm{ha})$, and plantation forest $(116.5 \pm 40 \mathrm{Mg} \cdot \mathrm{C} / \mathrm{ha})$ as shown in Figure 2.

Seasonal weather changes, i.e., temperature, significantly affected the amount of carbon stocks among the four different forest management types $\left(F_{4},{ }_{16}=.61\right.$, $P>0.05)$. The study indicated that the dry season (124.34 Mg.C/ha) had lower soil carbon stocks than the wet season (130 Mg. C/ha) as shown in Figure 3. The soils under glades (112.1 Mg. C/ha) and the ones under tree plantation (115.6 Mg.C/ha) recorded the lowest stocks during the dry season while both the undisturbed natural forest and fire disturbed natural forest had the highest (Figure 3).

The effect of seasonal weather variations on the soil carbon stocks was only significant in soils under glades but not for other forest management types. The weather changes and fire burning down natural forests did not have any significant effects on the soil carbon stocks. During the wet season period, the soils under glades had a remarkable increase in carbon stocks which was equal to those under natural forests (Figure 3).

The relationship between temperature (air) and soil carbon was statistically significant $(P>0.05)$ as shown in Figure 4 and Table 1. However, for soil moisture, the relationship with soil carbon was not significant (Figure 5).

\subsection{Soil Carbon Stocks and Bulk Density under Different Forest} Management Types. Generally, without considering the effect of weather changes, the undisturbed natural forest management had the highest mean bulk density of $0.66 \mathrm{~g} /$ $\mathrm{cm}^{3}$ while disturbed (fire) natural forest had the lowest mean of $0.59 \mathrm{~g} / \mathrm{cm}^{3}$ (Figure 6). These values were low compared to most normal mineral soils which have a bulk density of between $1.0 \mathrm{~g} / \mathrm{cm}^{3}$ and $1.5 \mathrm{~g} / \mathrm{cm}^{3}$.

The relationships between seasonal changes (temperature and moisture) in soil carbon stocks and different forest management types were significant $(P>0.01)$ after performing linear regression analysis where soil carbon stock was the response variable while bulk density was an explanatory variable. The linear relationships were highly significant with the relationship being stronger in soils under glades $\left(r^{2}=0.62\right)$ and less strong in the intact or undisturbed natural forest $\left(r^{2}=0.26\right)$, as shown in Figure 7 and Tables 2 and 3.

Seasonal weather variations significantly affected the soil bulk density, especially for disturbed and undisturbed natural forests and glades. The mean bulk densities for dry and wet seasons were $0.63 \mathrm{~g} / \mathrm{cm}^{3}$ and $0.62 \mathrm{~g} / \mathrm{cm}^{3}$, respectively. During the dry periods, there were no significant changes in the soil bulk density with soils under plantation recording marginally higher values of $0.65 \mathrm{~g} / \mathrm{cm}^{3}$ followed by natural forest disturbed 


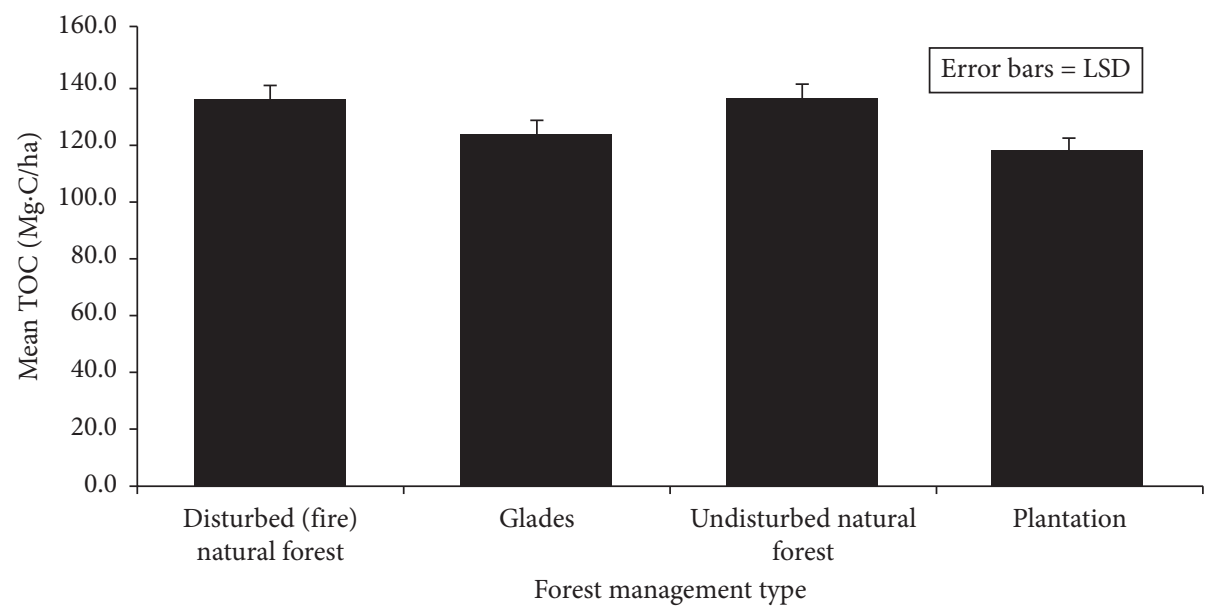

FIgURE 2: Soil carbon stocks under different forest management types.

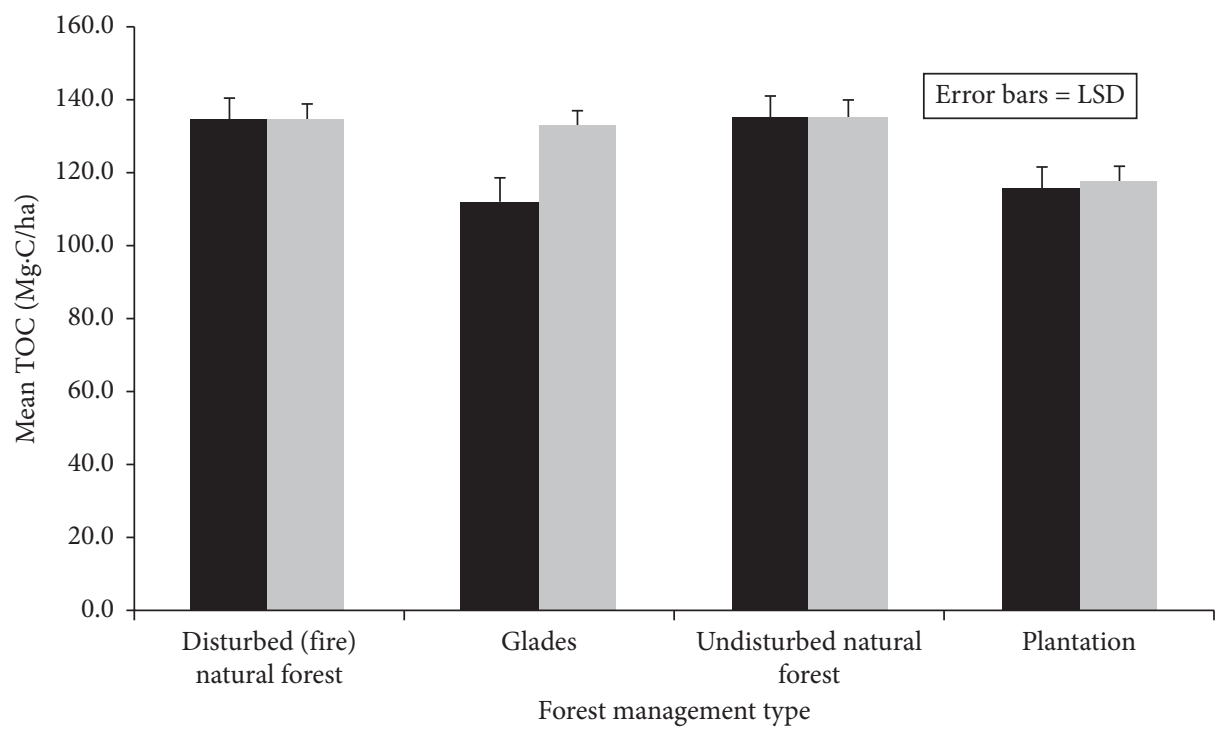

- Dry season

Wet season

FIGURE 3: Effects of seasonal weather variations on soil carbon stocks.

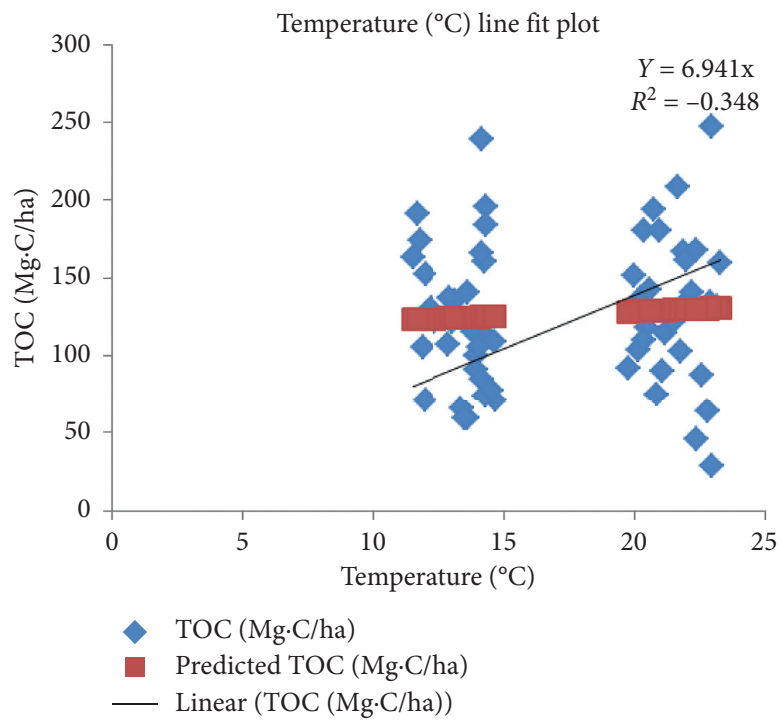

FIGURE 4: Relationship between temperature and soil carbon stocks. 
TABLE 1: Effect of temperature on soil carbon stocks under various forest management types.

\begin{tabular}{lcccc}
\hline \multirow{2}{*}{ Regression statistics } & \multicolumn{4}{c}{ Response variate: carbon stocks against temperature } \\
& Disturbed (fire) natural forest & Intact natural forest & Glades & Plantation \\
\hline Multiple $R$ & 0.37 & 0.18 & 0.080 & 0.34 \\
$R$ square & 0.14 & 0.034 & 0.006 & 0.11 \\
Adjusted $R$ square & 0.07 & -0.05 & -0.06 & 0.05 \\
Standard error & 32.53 & 38.10 & 65.90 & 40.11 \\
F-probability & 0.16 & 0.54 & 0.77 \\
\hline
\end{tabular}

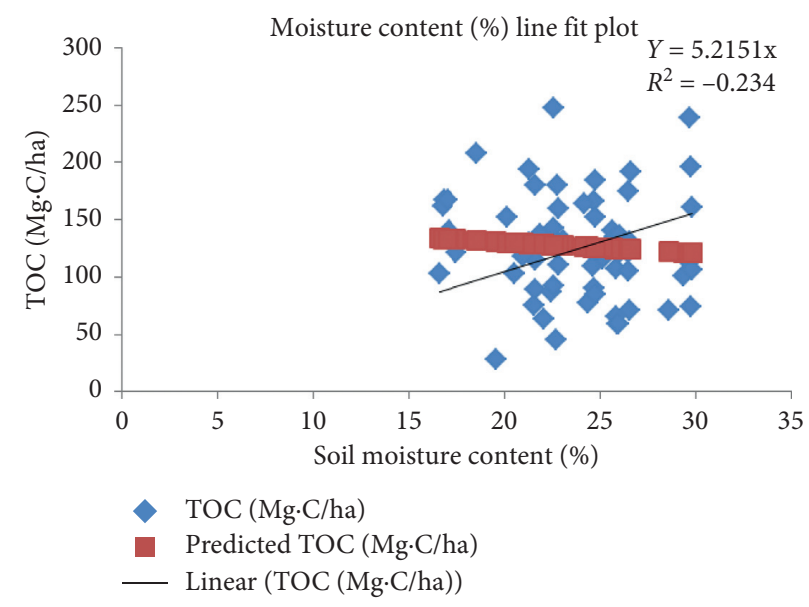

FIGURE 5: Relationship between soil moisture and soil carbon stocks.

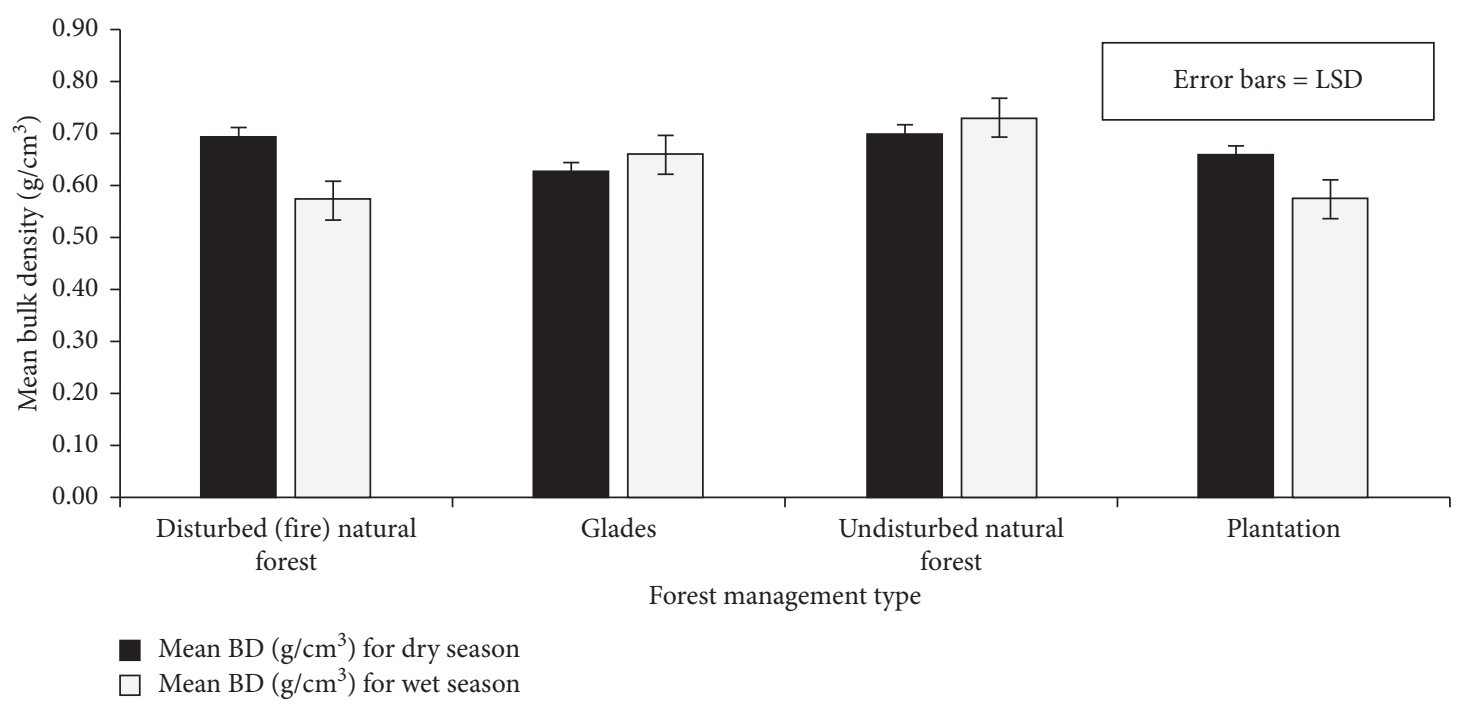

FIGURE 6: Soil bulk density under different forest management types.

by fire $\left(0.64 \mathrm{~g} / \mathrm{cm}^{3}\right)$ and both glades and undisturbed natural forest recording $\left(0.62 \mathrm{~g} / \mathrm{cm}^{3}\right)$. The wet season significantly affected bulk density with a drastic decrease in soils under natural forest disturbed by fires and plantations, i.e., from $0.64 \mathrm{~g} / \mathrm{cm}^{3}$ to $0.53 \mathrm{~g} / \mathrm{cm}^{3}$ and $0.65 \mathrm{~g} / \mathrm{cm}^{3}$ to $0.58 \mathrm{~g} / \mathrm{cm}^{3}$, respectively. However, the bulk density of soils under undisturbed natural forest and glades increased significantly, i.e., from $0.62 \mathrm{~g} / \mathrm{cm}^{3}$ to $0.70 \mathrm{~g} / \mathrm{cm}^{3}$ and $0.62 \mathrm{~g} / \mathrm{cm}^{3}$ to $0.66 \mathrm{~g} / \mathrm{cm}^{3}$ (Figure 6).

\section{Discussion}

The total soil carbon pool within a forest ecosystem is composed of both soil organic carbon and inorganic carbon and is determined by the balance between soil respiration, where carbon is released from the soil, and the incoming carbon from litterfall and rhizoid position [4, 29, 30]. Both factors can be influenced by favorable abiotic conditions and forest management practices and disturbances. 


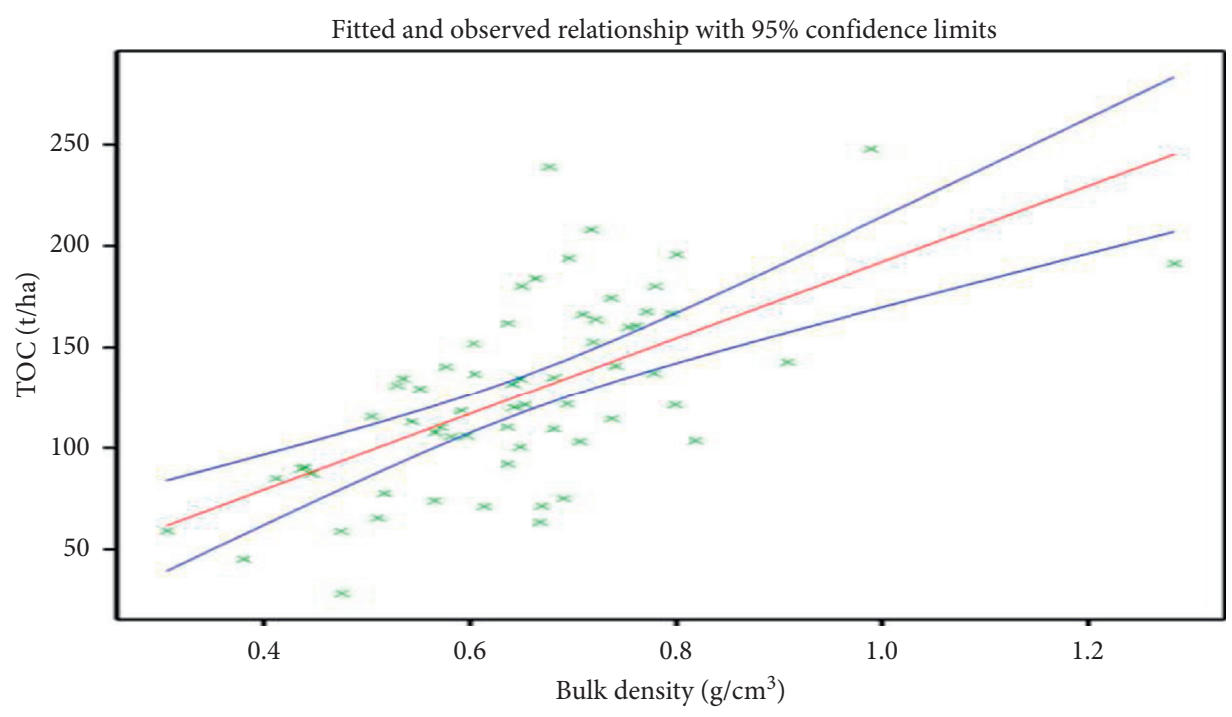

Figure 7: Relationship between carbon stocks and bulk density of soils.

TABLe 2: Summary of regression analysis.

\begin{tabular}{|c|c|c|c|c|c|}
\hline \multirow[b]{2}{*}{ Summary of analysis } & \multicolumn{5}{|c|}{$\begin{array}{l}\text { Response variate: TOC (t/ha), constant, bulk density } \\
\text { Fitted terms: } \mathrm{g} / \mathrm{cm}^{3}\end{array}$} \\
\hline & & & & & \\
\hline Source & d.f. & s.s. & m.s. & v.r. & F pr. \\
\hline Regression & 1 & 51514 & 51514 & 40.7 & $<0.001$ \\
\hline Residual & 62 & 78478 & 1266 & - & - \\
\hline Total & 63 & 129992 & 2063 & - & - \\
\hline Percentage variance accounted for 38.7 & - & - & - & - & - \\
\hline Standard error of observations is estimated to be 35.6 & - & - & - & - & - \\
\hline
\end{tabular}

TABLE 3: Regression statistics: linear relationships.

\begin{tabular}{lcccc}
\hline \multirow{2}{*}{ Regression statistics } & \multicolumn{2}{c}{$\begin{array}{c}\text { Response variate: total organic carbon against bulk density } \\
\text { Intact natural forest }\end{array}$} & $\begin{array}{c}\text { Glades } \\
\text { Plantation }\end{array}$ \\
\hline Multiple $R$ & 0.61 & 0.51 & 0.79 & 0.71 \\
$R$ square & 0.37 & 0.26 & 0.62 & 0.50 \\
Adjusted $R$ square & 0.33 & 0.21 & 0.59 & 0.46 \\
Standard error & 31.31 & 30.35 & 41.39 & 29.19 \\
$P$ value & 0.01 & 0.042 & 0.001 & 0.002 \\
\hline
\end{tabular}

In this study, the results showed that forest management types had no significant impacts on the soil carbon stock levels. Similarly, Marín-Spiotta and Sharma [14] noted that soil C stocks from secondary forests and plantations did not differ from each other.

The undisturbed natural forest had higher carbon stock levels per hectare followed by natural forest disturbed by fire, then glades, and plantation. The higher carbon stocks within natural forest could be explained by possible biotic factors such as the presence of a closed-canopy cover within the stratum which provides favorable conditions for carbon preservation through limiting decomposition of nonlabile carbon, and even where gaps exist in the canopy, the litter turnover compensates for losses [9, 19, 31, 32]. Results from [14] suggest that there is an optimal climatic range for maximum soil $\mathrm{C}$ stocks with wetter and cooler sites storing more soil $\mathrm{C}$ than drier and hotter regions. Many of the effects of temperature on soil organic matter decomposition and primary production are influenced by overall moisture availability [13]. These observations bring to fore the role played by abiotic conditions in soil carbon dynamics.

Furthermore, in this study, soils under forest recorded low bulk density as compared to what has been reported in other studies $[33,34]$. However, it is important to note that the soil bulk density often changes with land use and the soil carbon per unit ground area [35].

The importance of bulk density in carbon estimation cannot be overemphasized. A view similar to [13] this study noted how bulk density is critical in converting organic carbon percentage by weight to content by volume. At the 
same time, their study noted the variance is in relation to structural conditions of the soil, the mineralogy, and the water content. The variance underscores the fact that there will always be uncertainties in any estimate of soil carbon stocks at the national and continental scale [13, 35]. Soil organic matter is a key component of any terrestrial ecosystem, and any variation in its abundance and composition has important effects on many of the processes that occur within the system [13].

Therefore, the presence of decomposable organic matter from branches and litterfall increases the amount of soil carbon within a forest system. The processes could vary for fire disturbed natural forest, depending on the intensity and frequency of forest fires. High-intensity fire subjected to branches and forest floor litter will lead to instant oxidation where carbon stored in them moves to a gaseous state. Similarly, low-intensity fires may not interfere with soil carbon stock significantly, and this explains why despite the study site having experienced periodic fires in 2005, 2007, and 2014 [17], the soil carbon stocks were still higher than under glades and plantation.

Forest fires in most cases instantly consume aboveground biomass and forest floor carbon, and depending on the fire intensity, the belowground systems such as roots and soil carbon may be affected. Where incomplete combustion occurs, the woody biomass is converted to biochar or charcoal. Charcoal is resistant to microbial decomposition within the soils, and therefore, it can serve as an important long-term soil carbon pool, as well as increase overall soil quality [30]. The burnt natural forest study sites showed the formation of charcoal from previous forest fires and that could explain the high levels of soil carbon within the stratum. Fire does not necessarily lead to loss of soil C or N, but instead, it may cause increases in them by incorporation of charcoal and hydrophobic organic matter. However, this conclusion cannot fully be supported strongly by this study due to a brief period taken in the assessment as well as the scope of the study.

Glades are predominantly occupied by grass species that provide food to grazers, and therefore, its carbon stock levels will most likely be influenced by grazing. Grazing modifies soil organic carbon stocks through inflicting changes in plant productivity, root allocation of plant carbon, changes in species composition, and changes in physical soil properties [11].

Furthermore, glades being grass have a short life cycle and mineralize faster compared to leaves and litter of trees. However, due to the management of forest grazing within the carrying capacity by the Kenya Forest Service, the study area may not have experienced extreme grazing pressure and that explains the comparatively higher level of stocks recorded.

The soils under cypress plantation in this study had the lowest level of carbon due to inadequate levels of organic matter decomposition. The plantation had not been thinned or pruned due to restrictions imposed on plantation forests in Kenya that lasted 13 years [17].

The restrictions interfered with silvicultural operations especially pruning which could have added organic matter into the soil. Furthermore, the cypress tree has needleshaped litter that is more resistant to decomposition with similar observation noted by Zheng et al. [1] in a study in China where broadleaved species decomposed faster than needle litter species.

Plantation forest management mostly focuses on enhanced forest productivity and growing forest stocks by subjecting trees to several silvicultural operations that range from land preparation, pruning, thinning, and clear-cutting depending on the management regime. The amount of soil carbon gained during stand establishment and development depends, in large part, on the management of the stand between planting and harvest, as well as on climatic variables and species composition [30]. For example, a study on thinning in a Ponderosa pine stand found that, although soil respiration did not significantly change 3 and 16 years after thinning treatments, overall fine root biomass was lower even after 16 years, and overall soil carbon went from being a slight sink of carbon to being a significant source $(200 \mathrm{~g} \cdot \mathrm{C} /$ $\mathrm{m}^{2} / \mathrm{y}$ ) with thinning [9]. In addition, soils under Eucalyptus plantations had organic carbon reducing in the soil profile and with no significant changes in soil organic carbon levels under different ages between 3 and 40 years [36]. This was also attributed to the presence of phenolic compounds responsible for low decomposition rates of soil organic matter in some tree species especially Eucalyptus [37, 38].

It is common knowledge that soil organic carbon is a factor influenced by organic matter decomposition and accumulation whereby the decomposition is influenced by the presence of microbes as well as a favorable abiotic environment.

The rate and duration of organic matter accumulation are determined by forest management. Jandl et al. [29] observed that forest management activities influence soil carbon sequestration and emissions.

The results of soil carbon levels reported in this study compare well with $[4,39]$ who recorded carbon stocks ranges of $87-102 \mathrm{Mg} \cdot \mathrm{C} \mathrm{ha}{ }^{-1}$ in China and $123 \mathrm{Mg} \cdot \mathrm{C} \mathrm{ha}^{-1}$ for a tropical biome, respectively. Previous studies within Mau Forest by Were et al. and Kinyanjui $[33,40]$ reported carbon stock levels of between 42.0 and $193.4 \mathrm{Mg} \cdot \mathrm{C} \mathrm{ha}^{-1}$. In another study by Law et al. [41] in the USA, carbon stock levels of between $111.9 \mathrm{Mg} \cdot \mathrm{Cha}^{-1}$ and $142.4 \mathrm{Mg} \cdot \mathrm{Cha}^{-1}$ were recorded. In contrary results, a few similar studies reported lower soil carbon stocks levels; a study by Jandl et al. [29] in Europe reported values of $62-102 \mathrm{t} \cdot \mathrm{C} \mathrm{ha}^{-1}$ for plantation forest.

In Kenya, in $[42,43]$, soil carbon stock levels of 14-30 Mg.C ha ${ }^{-1}$ and $3.51-59.71 \mathrm{Mg} \cdot \mathrm{Cha}^{-1}$ were reported for Arabuko Sokoke natural forest and rehabilitated sites in Bamburi, respectively.

Muhati et al. [44] reported $12.5 \mathrm{Mg} \cdot \mathrm{Cha}^{-1}$ for Marsabit Forest Reserve, and Omoro et al. [45] documented a range from 78 to $146 \mathrm{Mg} \cdot \mathrm{Cha}^{-1}$ in Taita Hills forest. From these results, it was evident that Sururu forest reserve in the Mau Forest Complex had stable soil carbon stocks. The marked differences in carbon stocks are attributed to ecological, edaphic, climatic, anthropogenic, and possibly methodological variances between the current study and the other studies. 


\section{Conclusion}

The findings of this study indicated no significant differences in the carbon stocks among the four forest management types. The undisturbed natural forest had the highest mean soil carbon stocks while the plantation forest had the lowest. Seasonal weather changes (temperature) significantly affected the amount of carbon stocks among the four forest management types and showing a significant relationship. The relationship was stronger in soils under glades and weaker in the intact or undisturbed natural forest.

The study also indicated that the wet season had higher soil carbon stocks compared to the dry season. The effects of fires burning down natural forests did not have any significant changes in the soil carbon stocks. During the wet season period, the soils under glades had a remarkable increase in carbon stocks which is equal to those under natural forests.

Seasonal weather variations (temperature and soil moisture) significantly affected the soil bulk density especially for disturbed and undisturbed natural forests and glades with the soil registering higher bulk densities in the dry season. The bulk density values were low compared to most normal mineral soils.

From this study, the Sururu forest has stable soil carbon stocks, but forest disturbances have an impact on carbon stocks, and for effective management of forest towards climate stabilization, then disturbance should be minimized if not avoided.

\section{Data Availability}

The experimental data used to support the findings of this study may be released upon application to the management of both or either the Kenya Forest Service (KFS) and Kenya Forestry Research Institute (KEFRI) who can be contacted at director@kenyaforestservice.org and director@kefri.org, respectively. The additional data can be made available from the corresponding author upon request.

\section{Conflicts of Interest}

The authors declare that they have no conflicts of interest.

\section{Acknowledgments}

The authors acknowledge the management of both the Kenya Forest Service (KFS) and Kenya Forestry Research Institute (KEFRI) for granting permission for this study.

\section{References}

[1] H. Zheng, Z. Ouyang, W. Xu, X. Wang, Y. Tian, and Y. Tian, "Variation of carbon storage by different reforestation types in the hilly red soil region of southern China," Forest Ecology and Management, vol. 255, no. 3-4, pp. 1113-1121, 2008.

[2] J. P. Scharlemann, E. V. Tanner, R. Hiederer, and V. Kapos, "Global soil carbon: understanding and managing the largest terrestrial carbon pool," Carbon Management, vol. 5, no. 1, pp. 81-91, 2014.
[3] R. Lal, "Soil carbon sequestration to mitigate climate change," Geoderma, vol. 123, no. 1-2, pp. 1-22, 2004.

[4] R. Lal, "Forest soils and carbon sequestration," Forest Ecology and Management, vol. 220, no. 1-3, pp. 242-258, 2005.

[5] R. M. Maher, H. Asbjornsen, R. K. Kolka, C. A. Cambardella, and J. W. Raich, "Changes in soil respiration across a chronosequence of tallgrass prairie reconstructions," Agriculture, Ecosystems \& Environment, vol. 139, no. 4, pp. 749-753, 2010.

[6] S. Mishra, L. B. Chaudhary, and M. K. Jain, "Interaction of abiotic factor on soil $\mathrm{CO}_{2}$ efflux in three forest communities in tropical deciduous forest from India," Environimental Monitoring Assessesment, vol. 191, p. 796, 2019.

[7] D. W. Johnson and P. S. Curtis, "Effects of forest management on soil c and n storage: meta analysis," Forest Ecology and Management, vol. 140, no. 3, pp. 227-238, 2001.

[8] T. Karjalainen, A. Pussinen, J. Liski et al., "An approach towards an estimate of the impact of forest management and climate change on the european forest sector carbon budget: Germany as a case study," Forest Ecology and Management, vol. 162, no. 1, pp. 87-103, 2002.

[9] J. Campbell, G. Alberti, J. Martin, and B. E. Law, "Carbon dynamics of a ponderosa pine plantation following a thinning treatment in the northern sierra Nevada," Forest Ecology and Management, vol. 257, no. 2, pp. 453-463, 2009.

[10] E. J. Sayer, L. Lopez-Sangil, and J. A. Crawford, “Tropical forest soil carbon stocks do not increase despite 15 years of doubled litter inputs," Scientific Reports, vol. 9, Article ID 18030, 2019.

[11] L. Vesterdal and J. Leifeld, "Land-use change and management effects on soil carbon sequestration: forestry and agriculture." Greenhouse-gas budget of soils under changing climate and land use (burnout)," COST Action, vol. 639, pp. 25-32, 2007.

[12] D. P. Bradley and D. W. Scott, "Ecosystem carbon changes with woody encroachment of grassland in the northern great plains," Ecoscience, vol. 18, 2011.

[13] M. Henry, R. Valentini, and M. Bernoux, "Soil carbon stocks in ecoregions of Africa," Biogeosciences Discussions, vol. 6, no. 1, pp. 797-823, 2009.

[14] E. Marín-Spiotta and S. Sharma, "Carbon in reforested and plantation soils," Global Ecology and Biogeography, vol. 22, pp. 105-117, 2013.

[15] V. Saynes, C. Hidalgo, J. D. Etchevers, and J. E. Campo, "Soil C and $\mathrm{N}$ dynamics in primary and secondary seasonally dry tropical forests in Mexico," Applied Soil Ecology, vol. 29, no. 3, pp. 282-289, 2005.

[16] K. J. Teixeira, A. P. Allen, J. Gillooly, and J. Brown, "Temperature-dependence of biomass accumulation rates during secondary succession," Ecology Letters, vol. 9, no. 6, pp. 673-682, 2006.

[17] KFS, Sururu Forest Participatory Management Plan, Kenya Forest Service, Nairobi, Kenya, 2011.

[18] G. K. Tarus, B. K. Kirui, and G. Obwoyere, "Impacts of forest management type and season on soil carbon fluxes in Eastern Mau Forest, Kenya," African Journal of Ecology, vol. 57, no. 1, pp. 113-121, 2018.

[19] L. O. Olang and P. M. Kundu, "Land degradation of the mau forest complex in eastern africa: a review for management and restoration planning," in Environmental Monitoring, IntechOpen, London, UK, 2011.

[20] D. K. Langat, E. K. Maranga, A. A. Aboud et al., "Role of forest resources to local livelihoods: the case of East Mau forest ecosystem, Kenya," International Journal of Forestry Research, vol. 2016, Article ID 4537354, 10 pages, 2016. 
[21] M. K. Boitt, "Impacts of Mau forest catchment on the great rift valley lakes in Kenya," Journal of Geoscience and Environment Protection, vol. 4, no. 5, pp. 137-145, 2016.

[22] M. Mutugi and W. Kiiru, "Biodiversity, local resource, national heritage, regional concern, and global impact: the case of Mau Forest, Kenya," European Scientific Journal, vol. 11, no. 10, pp. 1-7, 2015.

[23] W. G. Sombroek, H. M. Braun, and B. J. Van der Pouw, Exploratory Soil Map and Agro-Climatic Map of Kenya, Report of Kenya Soil Survey, Nairobi, Kenya, 1980.

[24] P. M. Kundu, S. S. China, M. C. Chemelil, and J. O. Onyando, Detecting and quantifying land cover and land use change in Eastern Mau by remote sensing, Department of Agricultural Engineering, Egerton University, Box 536 Njoro, Njoro, Kenya, 2003.

[25] D. W. Nelson and L. E. Sommers, "A rapid and accurate method for estimating organic carbon in soil," Proceedings of the Indiana Academy of Science, vol. 84, pp. 456-462, 1975.

[26] J. R. Okalebo, K. W. Gathua, and P. L. Woomer, Laboratory methods of soil and plant analysis: a working manual, TSBFCIAT and SACRED Africa, Nairobi, Kenya, 2002.

[27] N. Trautmann and T. Richards, Moisture Content. Cornell Composting, Science and Engineering. Cornell Waste Management Institute, Ithaca, NY, USA, 1996, http://compost.css. cornell.edu/calc/moisture_content.html.

[28] VSN International, Genstat for Windows, VSN International, Hemel Hempstead, UK, 16th edition, 2013.

[29] R. Jandl, M. Lindner, L. Vesterdal et al., "How strongly can forest management influence soil carbon sequestration?" Geoderma, vol. 137, no. 3-4, pp. 253-268, 2007.

[30] A. Gershenson, J. Barsimantov, and J. Batista, Accounting for Carbon in Soils., White Paper for the Climate Action Reserve, Arlington, VA, USA, p. 46, 2010.

[31] Y. Peng, S. C. Thomas, and D. Tian, "Forest management and soil respiration: implications for carbon sequestration," Environmental Reviews, vol. 16, pp. 93-111, 2008.

[32] P. S. Duncker, S. M. Barreiro, G. M. Hengeveld et al., "Classification of forest management approaches: a new conceptual framework and its applicability to European forestry," Ecology and Society, vol. 17, no. 4, p. 51, 2012.

[33] K. Were, D. T. Bui, Ø. B. Dick, and B. R. Singh, "A comparative assessment of support vector regression, artificial neural networks, and random forests for predicting and mapping soil organic carbon stocks across an afromontane landscape," Ecological Indicators, vol. 52, pp. 394-403, 2015.

[34] V. Jeyanny, M. H. A. Husni, K. Wan Rasidah, B. Siva Kumar, A. Arifin, and M. Kamarul Hisham, "Carbon stocks in different carbon pools of a tropical lowland forest and a montane forest with varying topography," Journal of Tropical Forest Science, vol. 26, pp. 560-571, 2014.

[35] R. M. Gifford and M. L. Roderick, "Soil carbon stocks and bulk density: spatial or cumulative mass coordinates as a basis of expression?" Global Change Biology, vol. 9, no. 11, pp. 1507-1514, 2003.

[36] S. Nadir, C. Othieno, and S. Kebeney, "Nutrient dynamics in Eucalyptus plantations of different ages before and during intercropping," International Journal of Plant \& Soil Science, vol. 22, no. 1, pp. 1-13, 2018.

[37] S. W. Nadir and W. K. Ng'etich, "Effects of water soluble polyphenols in Eucalyptus grandis trees and their effects on crops and soil water repellency," Allelopathy Journal, vol. 44, no. 1, pp. 79-92, 2018.

[38] K. Min, C. Freeman, H. Kang, and S. Choi, "The regulation by phenolic compounds of soil organic matter dynamics under a changing environment," Biomed Research International, vol. 2015, Article ID 825098, 11 pages, 2015.

[39] X. T. Lüa, J. X. Yina, and J. W. Tanga, "Ecosystem carbon storage and partitioning in a tropical seasonal forest in southwestern China," Forest Ecology and Management, vol. 260, no. 10, pp. 1798-1803, 2010.

[40] M. J. Kinyanjui, The effect of human encroachment on forest cover,composition and structure in the Western Blocks of the Mau Forest Complex, Department of Natural Resources (Forestry) of Egerton University, Njoro, Kenya, 2009.

[41] B. E. Law, D. Turner, J. Campbell, O. J. Sun, S. Van Tuyl, and W. B. Cohen, "Disturbance and climate effects on carbon stocks and fluxes across western Oregon USA," Global Change Biology, vol. 10, no. 9, pp. 1429-1444, 2004.

[42] J. Glenday, "Carbon storage and emissions offset potential in an east african tropical rainforest," Forest Ecology and Management, vol. 235, no. 1-3, pp. 72-83, 2006.

[43] E. M. Mwikamba, Carbon sequestration potential of rehabilitated and natural forest sites of Bamburi Cement Limited, M. S. thesis, Kenyatta University, Mombasa county, Kenya, 2015.

[44] G. L. Muhati, D. Olago, and L. Olaka, "Quantification of carbon stocks in Mount Marsabit Forest Reserve, a sub-humid montane forest in northern Kenya under anthropogenic disturbance," Global Ecology and Conservation, vol. 14, Article ID e00383, 2018.

[45] L. M. Omoro, M. Starr, and P. K. Pellikka, "Tree biomass and soil carbon stocks in indigenous forests in comparison to plantations of exotic species in the Taita Hills of Kenya," Silva Fennica, vol. 47, no. 2, pp. 1-18, 2013. 